\title{
"Movimento dos sem palco": o Sarau da Cooperifa
}

\section{Clarice Ariela da Silva Cunha. Orientadora: Prof. ${ }^{\text {D }}$ Dr. ${ }^{\text {a }}$ Luciana Tatagiba}

\section{Resumo}

Essa pesquisa se insere na discussão a respeito da produção simbólica de identidades coletivas de movimentos sociais de periferia urbana, e faz parte de um projeto coletivo mais amplo que está começando a ser desenvolvido por membros do Núcleo de Pesquisa em Participação e Ação Coletiva da Unicamp (NEPAC), a respeito do movimento negro no Brasil. No presente trabalho buscamos pensar, a partir da experiência da Cooperativa Cultural da Periferia (Cooperifa), como a raça passa a ser um eixo central para construção da identidade e conformação dos sujeitos políticos periféricos. Dessa forma, foi feito o esforço de construir, do ponto de vista da ação coletiva e na perspectiva da Ciência Política, a história da cooperativa de poetas da Zona Sul de São Paulo.

\section{Palavras-chave:}

Movimentos culturais, identidade negra, Cooperifa.

\section{Introdução}

Essa pesquisa faz parte de um projeto coletivo que visa compreender as dinâmicas, fases, formas de atuação e intervenção do movimento negro no Brasil, na perspectiva da Ciência Política, uma vez que não há uma tradição de estudos sobre raça, principalmente que mobilizem a literatura de movimentos sociais na área.

Tendo em vista que quando surgem as organizações de movimentos de periferia, nos anos 70 e 80 , sua identidade política estava apoiada em matrizes discursivas cujo elemento organizador da ação coletiva era a categoria de classe e a questão racial não era tematizada de maneira central, 0 presente trabalho procura compreender como a raça se reposiciona como um eixo central no discurso e na mobilização dos sujeitos políticos periféricos, conformando sua identidade.

Diante disso, nos propomos a pensar, a partir da experiência da Cooperifa, como se dá esse processo de reposicionamento da questão racial como eixo identitário organizador da ação coletiva na periferia. Algumas perguntas que estamos buscando responder são: Quem são esses atores? Como, por que e quando surgem? Quem são seus inimigos? Quem ajudou a construir, material e simbolicamente, a Cooperifa? Quais são suas matrizes discursivas? A partir de que referências eles constroem seus discursos? Como se deram seus processos de identificação? Por que a categoria "classe", como entendida pelos atores dos anos 70 , não é o eixo principal que organiza sua ação coletiva? Como estão redefinindo e traduzindo "classe"? Como associam periferia, raça e classe? Quais os sentidos políticos dessa associação?

\section{Resultados e Discussão}

Tendo como principal hipótese a de que um dos mecanismos mais importantes que possibilita a raça ser colocada como eixo central identitário é a produção cultural e artística na periferia, nos pareceu interessante dirigir o olhar para uma organização que seja parte de um movimento cultural, como a Cooperifa.

Metodologicamente trabalhamos com análise de vídeos dos eventos e entrevistas já concedidas pelo idealizador e organizador da cooperativa, Sérgio Vaz, disponíveis online, bem como com sua própria produção a respeito da Cooperifa, principalmente sua obra "Cooperifa: uma antropofagia periférica", pelas quais pudemos mapear alguns elementos importantes para construir essa narrativa na perspectiva da Ciência Política e realizar uma posterior entrada no campo.

- O Sarau é um espaço de poesia, mas também de denúncia, contestação de exercício da cidadania, onde é colocada no centro do palco, sobretudo, a literatura negra e periférica. Começou com pequenos encontros e hoje tornou-se o maior sarau da cidade, onde se dá a ação poética e também ação política.

- Apesar de os saraus caracterizarem-se como um repertório de ação política coletiva, seus participantes tem a preocupação de preservar o caráter literário do seu movimento, de forma que seu discurso é sua própria produção artística. Como dito por Vaz, "todos os desabafos são feitos em estrofe".

- A importância da questão racial para seus participantes está presente de maneira latente, tanto nas falas do seu organizador quanto nos conteúdos das poesias declamadas, onde podemos observar a associação entre raça e classe como uma forma de identificação dos poetas como sujeitos políticos coletivos.

\section{Conclusões}

Os saraus da Cooperifa funcionam, não só como forma de expressão artística, mas como um espaço de elaboração simbólica e conformação de uma identidade política.

\section{Agradecimentos}

Ao PIBIC por viabilizar esse trabalho. À Luciana, por me fazer entender a pesquisa enquanto um processo, e aos colegas do NEPAC, pelos diálogos e trocas valiosas.

FELTRAN, Gabriel de Santis. Campos políticos; Os movimentos sociais e a política: notas de conclusão. In: Desvelar a política na periferia: histórias de movimentos sociais em São Paulo. Dissertação (Mestrado em Ciência Política) - UNICAMP, Campinas, SP, pp 156- 235, 2003.

SADER, Éder. Quando novos personagens entraram em cena: experiências, falas e lutas dos trabalhadores da Grande São Paulo (1970-80). Rio de Janeiro: Paz e Terra, 1988

VAZ, Sérgio. Cooperifa: uma antropofagia periférica. Rio de Janeiro: Aeroplano, 2008 